\title{
Przedsiębiorstwo jako aktywny podmiot kształtujący przestrzeń
}

Współczesne przemiany sprawiły, że inaczej pojmujemy dzisiaj czas i przestrzeń, co rzutuje na proces badawczy zjawisk zachodzących w gospodarce. Zgodnie z podstawowymi założeniami metodologicznymi geografii społeczno-ekonomicznej rzeczywistość należy badać w sposób całościowy, z uwzględnieniem jej zróżnicowań przestrzennych oraz ich zmienności w czasie. Analizowanie zjawisk na poziomie branż, gałęzi i działów gospodarki czy przemysłu w ujęciu jednostek terytorialnych - co określano strukturą przestrzenną - nie w pełni obrazuje złożoność współczesnych zależności występujących w przestrzeni. Przedmiotem mego zainteresowania jest badanie przedsiębiorstw - organizacji prowadzących działalność gospodarczą. Nurt badawczy geografii przedsiębiorstw (geography of enterprise, corporate geography), za prekursora której uznaje się powszechnie Roberta McNee, zaczął traktować przedsiębiorstwo jako aktywny podmiot funkcjonujący w przestrzeni. Wielkość i struktura przedsiębiorstwa sprawia, że przestrzeń ta może być kształtowana i nie ogranicza się jedynie do użytkowanego terytorium. Powiązania oraz wzajemne relacje firmy z otoczeniem zewnętrznym: ekonomicznym, technologicznym, prawnym, politycznym, kulturowym czy przyrodniczym, wpływają na wymiary i zasięg przestrzenny przedsiębiorstwa. Określenie wymiarów przedsiębiorstwa (wytwarzanej przez nie przestrzeni) i miary ich badania to problemy, z którym przyszło mi się zmierzyć.

W globalnej gospodarce przedsiębiorstwa są otaczane licznym gronem sprawnie działających firm, wyspecjalizowanych i realizujących konkretny fragment tworzonego łańcucha wartości. Wartość nie jest ponadto wytwarzana w łańcuchu jednokierunkowym, ale w ramach licznych transakcji wielokierunkowych pomiędzy przedsiębiorstwami. Należą do nich działania podstawowe (produkcyjne i handlowe), związane z fizycznym tworzeniem produktów (wyrobów i usług), ich dostawami, zbytem i obsługą oraz wspierające, obejmujące funkcjonowanie infrastruktury przedsiębiorstwa, zaopatrzenie, zarządzanie kadrą czy pracami badawczo-rozwojowymi. Rozwój technologii informatyczno-telekomunikacyjnych, umożliwiających sprawną koordynację działalności produkcyjnej, usługowej, handlowej czy badawczej, sprawił, że poszczególne działania podlegają fragmentyzacji, a następnie przemieszczaniu do jednostek organizacyjnych o różnej lokalizacji, a realizacja nie wymaga czasami fizycznej obecności. Przedsiębiorstwa, by realizować swe działania bardziej efektywnie, w coraz większym stopniu zorganizowane są na kształt organizacji sieciowych. Sieci przemysłowe tworzone są zarówno przez przedsiębiorstwa duże, jak i małe i średnie. 
Koncepcję usieciowienia (networking) w badaniach przestrzenno-ekonomicznych rozwijał w swych pracach z geografii przemysłu Tadeusz Stryjakiewicz. W koncepcji tej silnie eksponowana jest rola relacji pomiędzy aktorami w sieci. Umiejscowienie obiektu w sieci jest rezultatem zasięgu i intensywności jego powiązań. Uwarunkowań poszukuje się $\mathrm{w}$ specyficznie rozumianym otoczeniu sieci, tzw. zakorzenieniu/umocowaniu (embeddedness), czyli zdolności czy możliwości firm nawiązywania i utrzymywania powiązań w sieci. Opierając się na tej koncepcji teoretycznej na użytek niniejszej pracy autor zdefiniował pojęcie przedsiębiorstwa sieciowego ${ }^{1}$, charakteryzując jego cechy, przedstawiając niektóre typy i dokonując próby określenia jego wymiarów wraz z propozycjami metod pomiaru.

Na użytek niniejszej pracy organizacja sieciowa określona została jako układ współdziałania niezależnych pod względem organizacyjno-prawnym przedsiębiorstw, powiązanych kapitałowo lub nie, opierających swe działania na potencjale synergicznym w jednym obszarze funkcjonowania (lub większej ich liczbie) oraz na współpracy szerszej niż jednorazowy kontakt.

Charakterystycznymi cechami wspólnymi organizacji sieciowych są:

- elastyczność w działaniu,

- strategiczne współdziałanie,

- synergia - osiaganie celów wspólnych, które trudne lub niemożliwe byłyby do realizacji bez współpracy (uzyskiwanie tzw. wartości dodanej),

- możliwość wyboru strategicznego partnera,

- zbieżność realizowanych celów.

W ramach organizacji sieciowych możemy wyróżnić typy różniące się rodzajem wzajemnych relacji (personalne-instytucjonalne, formalne-nieformalne, okresowe-okazjonalne), określoną zbieżnością (wytwarzanego produktu, rynku czy grupy nabywców), strategią działania (fuzje, akwizycje, sieciowe układy współdziałania).

Szczególnie interesującym zagadnieniem dla geografa jest określenie wymiarów organizacji sieciowej, jej wielkości w ujęciu przestrzennym, zasięgu działania podmiotów związanych z daną siecią. Aktywność tych podmiotów, a nie odległości wpływają na zacieranie się tradycyjnie akceptowanych hierarchicznych wymiarów (lokalny, regionalny, krajowy, globalny). Wymiary te kształtują: skala działania, spójność organizacyjna, koordynacja działań, dynamika (elastyczność) zmian.

Najważniejsza wydaje się skala działania, określana poprzez liczebność układu (ilość podmiotów wchodzących w jej skład), charakterystykę podmiotów układu, tworzony łańcuch wartości, geograficzną przestrzeń działania, kapitałową „sieć wirtualną”. Wymiar organizacji sieciowej może określać także jej spójność poprzez siłę i charakter związków pomiędzy podmiotami, kierunek tych związków, a także ich aktywność lub nieaktywność. Wymiar koordynacji działań określić można poprzez ilość ośrodków koordynujących działalność w sieci oraz cyrkulację działań koordynacyjnych lub jej brak. Wymiar określający dynamikę zmian w organizacji sieciowej określić można badając zakres zachodzących zmian oraz częstotliwość zmian układu w sieci.

Sposoby pomiaru zaproponowane w badaniu wymiarów organizacji sieciowej określić mają:

- skalę działania, czyli liczbę podmiotów, ich wielkość, formy organizacyjno-prawne, geograficzną przestrzeń - przestrzeń obszarów objętych działaniem, łańcuch

${ }^{1} \mathrm{~W}$ swych rozważaniach będę używał zamiennie także nieco szerszego określenia - organizacja sieciowa (network organization, inter-firm network), mając na myśli przedsiebiorstwo. 
wartości (dzielony na szereg firm) wskazujący stopień dywersyfikacji działań oraz określona przez związki kapitałowe;

- spójność działań, czyli ich siłę wyrażoną przez związki (od najmniej do najbardziej trwałych) oparte na wzajemnym zaufaniu, na umowach formalnych relacjach kapitałowych lub związkach personalnych; kierunek związków - fakt współpracy z organizacją wchodzącą w skład sieci (problemem byłoby określenie ich w okresach, kiedy nie występowałaby potrzeba aktywnej współpracy pomiędzy danymi podmiotami), relacje związków aktywnych do nieaktywnych (pozwoli określić aktywność uczestników w sieci);

- koordynację działań, a więc liczbę ośrodków koordynujących zależność kapitałową (akcjonariusze), grupy interesów (interesariusze), zespoły ds. koordynacji (zadaniowe, na szczeblu operacyjnym); zmiany ośrodków koordynacji (zmiany uprawnień do koordynacji) zmiany akcjonariatu, zmiany kadry menadżerskiej, kierowniczej;

- dynamika zmian - zmienność liczebności w określonym czasie (gdy stałą jest liczebność w momencie stworzenia np. grupy kapitałowej, a zmienną - ubytek lub wzrost elementów sieci) ich częstotliwość (zmienną uzupełniającą, określająca, czy duży zakres zmian nie jest jedynie wynikiem jednorazowej restrukturyzacji, czy pewną tendencją).

Praca nie wyczerpuje tematu i stanowi jedynie próbę znalezienia wskaźników czy współczynników określających wymiary, zasięg przestrzenny działań współczesnych zmieniających się przedsiębiorstw, które stają coraz częściej przedsiębiorstwami sieciowymi.

Dynamiczne procesy globalizacji i postępująca integracja europejska sprawiają, że przedsiębiorstwa muszą dostosowywać się do zmiennych aspektów prowadzenia firm przy planowaniu produktów, usług czy zasobów finansowych i ludzkich. Tworzenie produkcji w sieci polega na coraz większych współzależnościach między przedsiębiorstwami, a nie zawsze są one korzystne dla obu stron, co podważa zasadę synergii w sieci. Istnieją znaczne różnice w sytuacji przedsiębiorstw w zależności od ich wielkości, ich położenia w łańcuchach wartości/ sieciach dostaw czy branżach, w których działają. Pojawiają się nowe problemy przed aktywnymi podmiotami działającymi w przestrzeni, w tym także przed przedsiębiorstwami sieciowymi. Stawia to nowe wyzwania przed geografami ekonomicznymi, a zwłaszcza geografią przemysłu identyfikacji zachodzących zjawisk wraz z występującymi relacjami w wymiarze przestrzennym.

\section{Literatura}

Chojnicki Z., 1999, Podstawy metodologiczne i teoretyczne geografii, Poznań

Domański B., 1997, Geografia przedsiębiorstw - niedoceniany nurt badań w polskiej geografii ekonomicznej, [w:] Domański B., Jackowski A., red., Geografia, człowiek, gospodarka, Kraków

Domański R., Marciniak A., 2003, Sieciowe koncepcje gospodarki miast i regionów, Warszawa

Domański R., 2005, Geografia ekonomiczna.Ujęcie dynamiczne, Warszawa

Gorzelak G., Smętkowski M., 2005, Metropolia i jej region w gospodarce informacyjnej, Warszawa

Lisowski A. 2003, Koncepcje przestrzeni w geografii człowieka, Warszawa

Łobos K., 2005, Organizacje sieciowe, [w:] Krupski R., red., Zarzqdzanie przedsiębiorstwem w turbulentnym otoczeniu, Warszawa

Rogacki H., red., 2003, Problemy interpretacji wyników metod badawczych stosowanych w geografii społeczno-ekonomicznej i gospodarce przestrzennej, Poznań 
Strategor, 2001, Zarzqdzanie firma, Warszawa

Stryjakiewicz T., 2001, Orientacje teoretyczno-metodologiczne w geografii przemystu a transformacja gospodarki, Warszawa-Kraków -Rzeszów

Stryjakiewicz T., 2001, Koncepcja usieciowienia w badaniach przestrzenno-ekonomicznych, [w:] Rogacki H., red. Koncepcje teoretyczne i metody badań geografii społeczno ekonomicznej i gospodarki przestrzennej, Poznań

Stryjakiewicz T., Wajda J., 2003, Organizacja przestrzenna grup kapitałowych jako problem badawczy geografii ekonomicznej, [w:] Zioło Z., Makieła Z., red., Przemyst w procesie globalizacji, Prace Komisji Geografii Przemysłu PTG, nr 6, Warszawa-Kraków

Stryjakiewicz T., 2004, Sieci gospodarcze $w$ Polsce $w$ warunkach transformacji systemowej, [w:] Parysek J.J., red., Rozwój regionalny i lokalny 1989-2002 w Polsce w latach, Poznań

Tobolska A., 2006, Strategie globalne a nowe formy organizacji przedsiębiorstw transnarodowych, [w:] Zioło Z., Rachwał T., red., Rola przedsiębiorczości w podnoszeniu konkurencyjności społeczeństwa i gospodarki, Warszawa-Kraków

Wieloński A., 2004., Lokalizacja działalności gospodarczej. Teoretyczne podstawy, Warszawa

Wieloński A., 2005, Geografia przemystu, Warszawa

Yip G.S., 2004, Strategia globalna, Warszawa

Zioło Z., 2001, Struktura branżowa i koncentracja przestrzenna wiodacych światowych firm przemystowych, [w:] Zioło Z., red., Problemy przemian struktur przemystowych w procesie wdrażania regut gospodarki rynkowej, Kraków

Zorska A., 2007, Korporacje transnarodowe. Przemiany, oddziaływania, wyzwania, Warszawa

\section{The enterprise as the active subject formative of the space}

The analysis of occurrences on the level of lines, branches and divisions of the economy or the industry with respect to territorial units - which is referred to as the spatial structure - does not fully picture the complexity of present dependences occurring in the space.

The object of my interest is the research of enterprises - organizations leading economic activity.

The research stream of geography of enterprises (corporate geography), whose universally acknowledged precursor is Robert McNee, began to treat the enterprise as the active subject working in the space.

The size and structure of an enterprise causes this space to be shaped, and not only limited to the used territory.

Connections and interrelations of firms with the external environment: economic, technological, legal, political, cultural and natural, bear on the measurements and the spatial range of the enterprise.

Determining the measures of an enterprise (the space shaped by it) and methods of their investigation are problems I have faced.

In global economy, enterprises are surrounded by a wide circle of efficiently working firms, specialized, and realizing particular fragments of the created chain of value.

Besides, value is not produced in a one-way chain, but within a number of multi-directional transactions between enterprises.

Among them are basic activities (productive and commercial) connected with the physical creation of products (products and services), with their delivery, sale, and service, supporting the functioning of the enterprise infrastructure, supply, human resources and research and development works.

Enterprises, in order to realize their own activities more efficiently, to a greater and greater degree are organized on the pattern of network organizations. 
Industrial networks are created both by large enterprises and small and middle-sized firms. The idea of networking was developed in spatial-economic research by Tadeusz Stryjakowski, in his works in industrial geography.

For the present paper, the author defines the notion of a network enterprise, characterizes its features, presents the types and makes an attempt at determining the measurements of such enterprises and suggests methods of measurement. 